We are grateful to Professor P. D. Griffiths and his staff for the biochemical estimations, to $\mathrm{Dr}$, W. K. Stewart for permission to publish these cases, and to Dr. P. G. Aungle and Professor I. R. C. Batchelor for their helpful comments.

Requests for reprints should be sent to Dr. D. C. Anderson.

\section{REFERENCES}

Black, D. A. K., and Milne, M. D. (1952). Clin. Sci., 11, 397 Chakmakjian, Z. H., and Bethune, J. E. (1966). New Engl. J. M.ed., 275,

Chaplin, H., Clark, L. D., and Ropes, M. W. (1951). Amer. 7. med. Sci.,

Cohen, S. I. I., Fitzgerald, M. G., Fourman, P., Grifiths, W. J., and de Wardener, H. E. (1957). Quart. F. Med., 26, 423.

Coppen, A., and Shaw, D. M. (1963). Brit. med. Y., 2, 1439.

Epstein, F.' H. (1960). \%. chron. Dis., 11, 255.

Ferris, T., Kashgarian, M., Levitin, H., Brandt, I., and Epstein, F. H. (1961). New Engl. Ұ. Med., 265,'924.
Finberg, L., and Harrison, H. E. (1955). Pediatrics, 16, 1.

Fitz, T. E., and Hallman, B. L. (1952). Arch. intern. Med., 89, 547.

Flach, F. F. (1964). Brit. F. Psychiat., 110, 588.

Gill, J. R., and Bartter, F. C. (1961). J. clin. Invest., 40, 716

Guyer, P. B. (1965). Brit. med. Ұ., 1 , 169.

Heckman, B. A., and Walsh, J. H. (1967). New Engl. F. Med., 276, 1082 .

Henson, R. A. (1966-7). F. roy. Coll. Phycns Lond., 1, 41. Huth, E. J., Mayock, R. L., and Kerr, R. M. (1959). Amer. F. Med.,

Kenny, F. M., and Holliday, M. A. (1964). New Engl. F. Med., 271, 708.

Lehrer, G. M., and Levitt, M. F. (1960). 7. Mt Sinai Hosp., 27, 10.

Mayer-Gross, W., Slater, E., and Roth, M. (1960). Clinical Psychiatry, 2nd ed. London.

Nordin, B. E. C. (1959). Lancet, 2, 368.

Sanderson, P. H. (1967). Brit. med. F., 1, 679.

Schwartz, W. B., and Relman, A. S. (1967). New Engl. 7. Med., 276, 452 .

Shaw, D. M., and Coppen, A. (1966). Brit. F. Psychiat., 112, 269.

Sterling, F. H., and Rupp, J. J. (1967). Acta endocr. (Kbh.), 54, 380.

Verner, J. V., Engel, F. L., and McPherson, H. T. (1958). Ann. intern. Med., 48, 765 .

Wolff, H. P., et al. (1968). Lancet, 1, 257.

\title{
Reticulum Cell Sarcoma after Renal Homotransplantation and Azathioprine and Prednisone Therapy
}

\author{
P. B. DOAK,* M.B., M.R.C.P., M.R.A.C.P. ; J. Z. MONTGOMERIE, ${ }^{*}$ M.B., M.R.A.C.P. \\ J. D. K. NORTH, $\dagger$ D.PHIL., M.R.C.P., F.R.A.C.P. ; F. SMITH, $\ddagger$ M.B., F.C.PATH. M.C.P.A.
}

Brit.med. F., 1968, 4, 746-748.

\begin{abstract}
Cummary : Two patients developed reticulum cell sarcomata after they had been treated with azathioprine and prednisone in the course of cadaveric renal transplantation. Both had terminal widespread herpes simplex virus infection.

Immunosuppressive therapy could be responsible for an increased risk of malignant lymphomata either directly or by facilitating infection with oncogenic viruses.
\end{abstract}

\section{Introduction}

Neoplasia has been postulated as a potential complication of depression of the immune system by drugs (Swanson and Schwartz, 1967). We report two cases in which reticulum cell sarcomata developed after renal homotransplantation and treatment with azathioprine and prednisone.

\section{Case 1}

The patient, a 34-year-old man with renal failure due to chronic glomerulonephritis, was started on regular haemodialysis treatment in June 1966. Bilateral nephrectomy was performed in September, and a disrupted wound left him with a large ventral hernia. In November he received two unsuccessful kidney transplants from cadavers, receiving treatment with azathioprine and prednisone for seven days. Regular haemodialysis treatment was continued until April 1967, when a third kidney was transplanted from a 38-yearold man who died of cerebral trauma. Necropsy of the donor showed no evidence of neoplasia. The kidney functioned well, and the creatinine clearance rose to $70 \mathrm{ml} . / \mathrm{min}$. within one month of transplantation. Four mild episodes of transplant rejection with temporary decline in renal function were treated with high doses of

* Physician, Medical Unit, Auckland Hospital, Auckland, New Zealand. t Professor of Medicine, University of Auckland, Auckland, New Zealand. $\ddagger$ Pathologist, Auckland Hospital, Auckland, New Zeala:ad. prednisone. Actinomycin C $400 \mu \mathrm{g}$. was also given three times. The mean daily dose of azathioprine was $75 \mathrm{mg}$. The mean prednisone dose for the first three months was $60 \mathrm{mg}$. daily, and thereafter $35 \mathrm{mg}$. daily. The ventral incisional hernia was repaired with a Teflon patch in July, but a staphylococcal infection of the wound developed and persisted until death.

In September he developed extensive herpetic lesions on the lips and inside his mouth. Candida albicans was cultured from the oral swab, and he was given local nystatin and gentian violet, followed by intravenous amphotericin (120 mg. in four days). The tongue became ulcerated, and the oral lesions extended to involve the oesophagus. He had marked cervical adenopathy, and both epitrochlear glands were enlarged.

During the final six weeks of life he also received penicillin and cloxacillin and kanamycin. Local iododeoxyuridine $1 \%$ was applied to the herpetic lesions without benefit. His general condition deteriorated steadily, though renal function remained satisfactory until he died in November 1967.

At necropsy there was severe ulceration of the skin of the lips, the right side of the face, and both eyelids. There was a large ulcer near the tip of the tongue measuring $2 \mathrm{~cm}$. across. Histological examination of the tongue showed the ulcerated surface to contain many Gram-negative bacilli, Gram-positive cocci, and small numbers of the spores and hyphae consistent with $C$. albicans. Deep to the area of ulceration and extending among the striated muscle and fat was a malignant tumour. The lower two-thirds of the oesophagus showed many deep ulcers, small numbers of Grampositive cocci, and Gram-negative bacilli, but no fungal elements were seen. In the submucosa were small numbers of cells with large nuclei, often vacuolated, containing viral inclusion bodies. In the deeper parts of the submucosa were small clumps of tumour cells.

The liver weighed $2,940 \mathrm{~g}$. When cut across it showed many tumour nodules, the largest measuring $1.5 \mathrm{~cm}$. across (Fig. 1). They were red with mottled white areas. Marked fatty degeneration was present with no increase in fibrous tissue or any bile duct proliferation. Many small necrotic areas in which liver cells had disappeared and which contained degenerating red cells were seen. Among this necrotic tissue, but also in viable liver tissue, there were malig- 
nant tumour cells. The malignant cells on the tongue, oesophagus, and liver were similar in appearance. They were polygonal with scanty pale cytoplasm and large darkly staining nuclei. The nuclei were often crenated with a well-marked membrane, and many had a nucleolus. Some cells were multinucleated, and a few had giant nucleoli. Mitotic figures occurred in small numbers. There was an increase in reticular fibres which surrounded some tumour cells. The tumour had the appearance of a malignant lymphoma of the subtype reticulum cell sarcoma (Fig. 2).

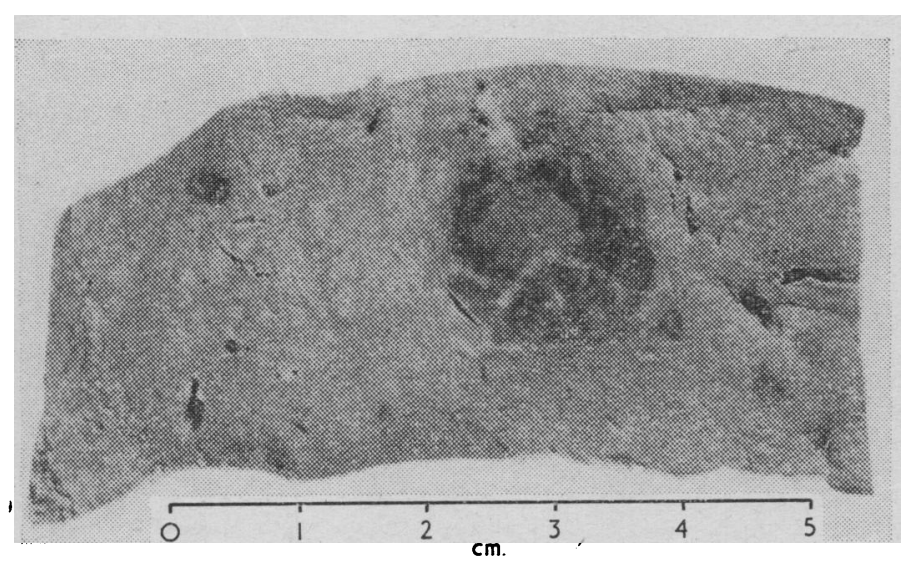

FIG 1.-Case 1 Slice of liver showing nodules of tumour.

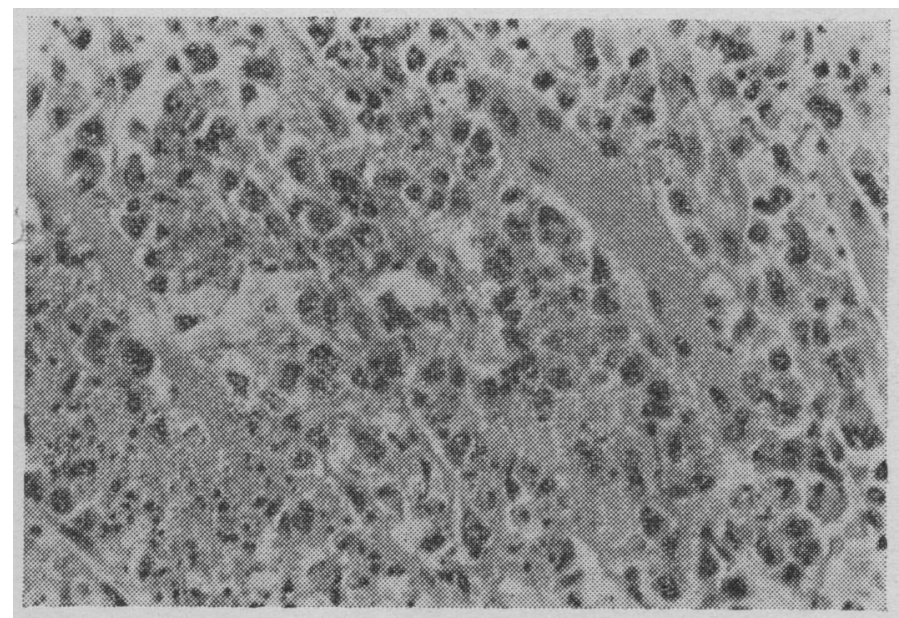

FIG. 2.-Case 1. Section of tongue showing tumour infiltrating striated muscle. (H. and E. $\times 330$.)

\section{Case 2}

A 46-year-old woman with chronic glomerulonephritis was given regular haemodialysis treatment for three months before receiving a kidney from a 21-year-old man who died as a result of head injury. Necropsy showed no evidence of neoplasia. After seven days of oliguria the kidney functioned well, and the creatinine clearance was $70 \mathrm{ml} . / \mathrm{min}$. She had three easily reversible episodes of decreased renal function during the first three months after transplantation. The mean daily dose of prednisone during this time was $60 \mathrm{mg}$. daily and azathioprine $50 \mathrm{mg}$. daily. After this azathioprine was continued in a dose of $50-75 \mathrm{mg}$. daily and prednisone $20-30 \mathrm{mg}$. daily until her death nine months after transplantation. Three months after transplantation she developed severe labial herpes simplex infection, which spread to involve the nose. The labial lesions healed after two months, but the nasal lesions progressed and led to destructive rhinitis with septal perforation, which was still present at the time of death. For the month before death she was severely toxic with systemic staphylococcal infection, including lung abscess.

At necropsy a softened area $3 \mathrm{~mm}$. across was seen close to the surface of the right parietal cortex. Some necrotic material containing nuclear debris was seen. Hyphae and spores consistent with $C$. albicans were present in very small numbers. Adjacent to this area were masses of tumour cells, some of which were arranged around blood vessels (Fig. 3). The rest of the brain was normal. The cells were similar in type to those seen in Case 1.

In the right lung intranuclear inclusions consistent with viral inclusions were seen in cells lying in the alveolar spaces. Spores and hyphae were also present. Tumour cells were not seen in the lung or other organs.

\section{Discussion}

Burnet (1967) postulated that the immune system plays an important part in preventing or restricting the growth of neoplastic cells, and the concept that neoplasia might occur as a complication of treatment with immunosuppressive agents was suggested by Swanson and Schwartz (1967). Malignant lymphomata in the present two cases may have resulted from immunosuppressive therapy, which was given for eight and nine months after renal transplantation. Marked immunosuppression in these patients was shown by the prolonged survival of the transplanted kidney, transient leucopenia, and marked susceptibility to infection. Of 38 patients receiving renal homografts in this unit 11 others have died. In none of these was neoplasia detected.

A case of reticulum cell sarcoma following renal transplantation and treatment with azathioprine, prednisone, and antilymphocyte serum has occurred in Edinburgh (Woodruff, 1968), and four similar cases have been quoted (Lancet, 1968). Our patients had the same type of lymphoma, and it is of great interest that primary neoplasms occurring after renal homotransplantation have been of the reticuloendothelial system.

Other examples of neoplasms appearing after renal homotransplantation have apparently been transplanted. On four occasions a neoplasm of a type present in the donor's body but not obviously involving the kidney has appeared in the recipient after renal homotransplantation (Dossetor, 1965 ; McPhaul and McIntosh, 1965 ; Martin et al., 1965; Wilson et al., 1968), and in one case (Wilson et al., 1968) cessation of immunosuppressive therapy may have contributed to the apparent disappearance of the tumour after partial excision. These patients appeared to have an impaired ability to prevent or restrict the growth of neoplastic cells which was probably due to treatment with immunosuppressive drugs.

That the immunosuppressive agents themselves may have produced lymphomata where these have appeared after renal homotransplantation is suggested by the fact that treatment with azathioprine or mercaptopurine has been associated with an increased incidence of lymphomata in NZB and NZB/NZW hybrid mice (Casey, 1967, 1968a, 1968b) and in $\mathrm{C}_{57} \mathrm{BL}$ mice (Doell et al., 1967). This effect could have been produced by interference with nucleic acid metabolism of the rapidly dividing cell or by activation of an oncogenic virus. The latter

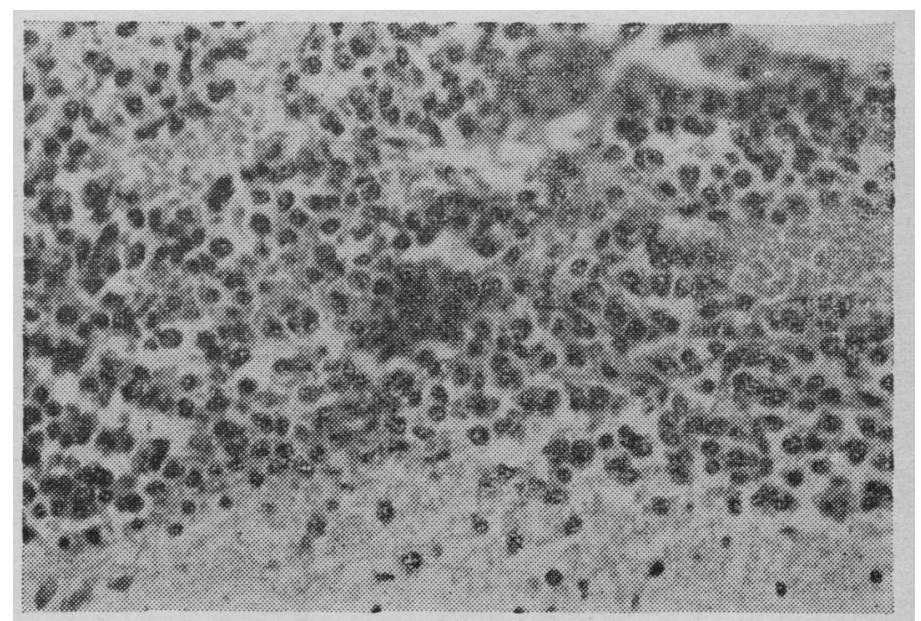

FIG. 3.-Case 2. Section of brain showing tumour. (H. and E. $\times 330$.) 
possibility receives some support from the finding of virus particles, possible oncogenic, in cells of NZB mice (East et al., 1967). Other immunosuppressive agents might have similar effects.

Woodruff (1968) reported the recurrence of reticulum cell sarcoma in one patient who died 25 months after transplantation, and had received antilymphocyte serum in addition to azathioprine and prednisone. Antilymphocyte serum has been shown to be a potent immunosuppressive agent in animals (Levey and Medawar, 1966 ; Lance and Medawar, 1968), and its use in man has apparently contributed to increased survival rates of transplanted kidneys from live related donors (Starzl et al., 1968). This serum has also been used in experiments designed to test the role of the immune system in limiting the growth of malignant tumours. The results of several experiments are consistent with the theory that the intact immune system does limit the growth of neoplastic cells but do not provide unequivocal proof (Allison and Law, 1968 ; Deodhar et al., 1968 ; Hellman et al., 1968). The finding that the administration of antilymphocyte serum to mice infected with Maloney leukaemogenic virus results in the development of reticulum sarcomas is of special interest (Allison and Law, 1968).

The extensive suggestive evidence that viruses may produce malignant lymphoproliferative disease in the presence of immunological abnormalities has been reviewed by Schwartz and André-Schwartz (1968). Since both our patients had extensive herpes simplex infection for some weeks before death the possible role of this virus in the production of lymphomata deserves consideration. Herpes-like virus has been incriminated in the pathogenesis of lymphomatosis of fowls (Churchill and Biggs, 1967), and another herpes-like virus, EBV, has been found in the cells of Burkitt's lymphoma grown in tissue culture (Epstein et al., 1964). However, since herpes virus infections are common after renal homotransplantation, and in our series of 38 cases has contributed to death in four, it is probable that this infection was associated with prolonged immunosuppressive therapy and coincident with, rather than causative of, the malignant lymphoma.

It is possible that the increased cellular activity of the immune system in response to a transplanted organ would increase the tendency for neoplastic cells to develop by spon- taneous mutation. The occurrence of lymphomata in mice undergoing the graft-versus-host reaction would be consistent with this view (Schwartz and Beldotti, 1965).

The mechanism of production of reticulum cell sarcomata in patients after renal homotransplantation is not known, and the cause, which may be multifactorial, can only be speculated about. It seems likely, however, that the use of potent immunosuppressive agents, probably including antilymphocyte serum, will lead to an increased incidence of primary neoplasia, especially malignant lymphoma.

We thank Mr. A. J. Duke and Mr. C. H. Maclaurin for performing the renal homotransplant operations on these patients.

\section{REFERENCES}

Allison, A. C., and Law, L. W. (1968). Proc. Soc. exp. Biol. (N.Y.), $127,207$.

Burnet, F. M. (1967). Lancet, 1, 1171.

Casey, T. P. (1967). Proc. Univ. Otago med. Sch., 45, 48.

Casey, T. P. (1968a). Clin. exp. Immunol., 3, 305.

Casey, T. P. (1968b). Aust. F. exp. Biol. med. Sci., 46, 327

Churchill, A. E., and Biggs, P. M. (1967). Nature (Lond.), 215, 528.

Deodhar, S. D., Crile, G., jun., and Schofield, P. F. (1968). Lancet, 1, 168 .

Doell, R. G., De Vaux St. Cyr, C., and Grabar, P. (1967). Int. F. Cancer, 2, 103

Dossetor, J. B. (1965). Unpublished data. Presented at Washington Conference on Human Kidney Transplants.

East, J., Prosser, P. R., Holborow, E. J., and Jaquet, H. (1967). Lancet $1,755$.

Epstein, M. A., Achong, B. G., and Barr, Y. M. (1964). Lancet, 1, 702.

Eellmann, K., Hawkins, R. I., and Whitecross, S. (1968). Brit. med. F., 2, 533 .

Lance, E. M., and Medawar, P. B. (1968). Lancet, 1, 1174.

Lancet, 1968, 1, 1298 .

Levey, R. H., and Medawar, P. B. (1966). Ann. N.Y. Acad. Sci., 129, 164.

McPhaul, J. J., and McIntosh, D. A. (1965). New Engl. F. Med., 272,

Martin, D. C., Rubini, M., and Rosen, V. J. (1965). F. Amer. med. Ass., 192, 752 .

Schwartz, R. S., and André-Schwartz, J. (1968). Ann. Rev. Med., 19, 269.

Schwartz, R. S., and Beldotti, L. (1965). Science, 149, 1511.

Starzl, T. E., Groth, C. G., Terasaki, P. I., Putnam, C. W., Brettschneider, L., and Marchioro, T. L. (1968). Surg. Gynec.'Obstet., $126,1023$.

Swanson, M. A., and Schwartz, R. S. (1967). New Engl. F. Med., 277,

Wilson, R. E., Hager, E. B., Hampers, C. L., Corson, J. M., Merrill, J. P., and Murray, J. E.'(1968). New Engl. ₹ Med., 278, 479.

Woodruff, M. P. A (1968). Antibiot. et Chemother. (Basel). In press.

FOR DEBATE ...

\title{
Differences between $\alpha$ - and $\beta$-Chain Mutants of Human Haemoglobin and between $\alpha$ - and $\beta$-Thalassaemia. Possible Duplication of the $\alpha$-Chain Gene*
}

\author{
H. LEHMANN, $\dagger$ M.D., SC.D., F.R.C.P. ; R. W. CARRELL, $\ddagger$ M.B., B.SC., PH.D.
}

Frit. med.7., 1968, 4, 748-750

\begin{abstract}
Summary : Human adult haemoglobin consists of two $\$$ unlike pairs of polypeptide chains, and can be described as $\alpha_{2} \beta_{2}$. Amino-acid substitutions in either of the two types of chain result in $\alpha$ - and $\beta$-chain variants. In thalassaemia, which causes a lowered production of haemoglobin, the $\alpha$ or the $\beta$ chain can be affected, the result being $\alpha$ - or $\beta$-thalassaemia. There is a quantitative difference in the proportion of $\alpha$ - and $\beta$-chain variants to normal haemoglobin in the respective heterozygotes, and there is also a difference in the pattern of inheritance of $\alpha$ - and $\beta$-thalassaemia : these could possibly be explained by assuming that man has one gene for the $\beta$ - and two for the $\alpha$-chain.
\end{abstract}

\section{Introduction}

The globin polypeptide chains of the known animal haemoglobins and of the myoglobins differ considerably in their primary amino-acid sequence, but they resemble each other in their three-dimensional (tertiary) structure. An amino-acid residue of such a chain can be denoted by the number it occupies in the sequence. Normal adult human haemoglobin, Haemoglobin $\mathrm{A}$, is formed by two pairs of unlike chains, $\alpha$ and $\beta$,

* From the Medical Research Council Abnormal Haemoglobin Research Unit, University Department of Biochemistry, Cambridge.

† Professor of Clinical Biochemistry, University of Cambridge. church, New Zealand. 